\title{
Effects of Paper-Mill Sludge as a Mulch versus Topsoil Incorporation on Potassium Uptake and the Grain Yield of Rain-Fed Wheat in a High Specific Surface Loess Soil with Illite Dominance in Clay Fraction
}

\author{
S. Amini, ${ }^{1}$ S. A. R. Movahedi Naeini, ${ }^{2}$ and K. Mashayekhi ${ }^{3}$ \\ ${ }^{1}$ Gorgan University of Agricultural Sciences and Natural Resources, Gorgan 49189-43464, Iran \\ ${ }^{2}$ Soil Science Department, Gorgan University of Agricultural Sciences and Natural Resources, Gorgan 49189-43464, Iran \\ ${ }^{3}$ Horticulture and Landscape Department, Gorgan University of Agricultural Sciences and Natural Resources, \\ Gorgan 49189-43464, Iran
}

Correspondence should be addressed to S. A. R. Movahedi Naeini, salirezam@yahoo.com

Received 14 June 2011; Accepted 15 September 2011

Academic Editor: Giuseppe Corti

Copyright (c) 2012 S. Amini et al. This is an open access article distributed under the Creative Commons Attribution License, which permits unrestricted use, distribution, and reproduction in any medium, provided the original work is properly cited.

\begin{abstract}
A field experiment with rain-fed winter wheat investigated the nutritional aspects of paper-mill sludge as a mulch and incorporated into the topsoil. Treatments with chemical fertilizers were also used as controls. Paper-mill sludge used as mulch with high rate $\left(100 \mathrm{MG} \mathrm{ha}^{-1}\right.$ ) and also the combined $\mathrm{N}$ and $\mathrm{K}$ mineral fertilizer treatments increased yield when a low potassium otherwise caused potassium deficiency in wheat with high specific surface soil. High soil Ca: K molar ratio by incorporation lowered potassium uptake and yield, with visual symptoms of potassium deficiency. A very high Gapon selectivity coefficient $\left(\mathrm{K}_{\mathrm{G}}\right)$ for $\mathrm{K}$ exchange against $\mathrm{Ca}+\mathrm{Mg}\left(16.58(\mathrm{~L} / \mathrm{mole})^{0.5}\right)$ produced a nonlinear normalized exchange isotherm in favor of potassium with these soils containing high illite. $\mathrm{Ca}$ and $\mathrm{K}$ which are released by sludge decomposition are diverged in soil when mobilized by rain infiltration, lowering Ca: K molar ratio. Low soil Ca: K molar ratio may be expected by surface sludge application relative to incorporation, due to greater rain infiltration through upper soil layers and their effluent pore volumes per unit depth. Ca from triple superphosphate by the $\mathrm{P}, \mathrm{N}$, and $\mathrm{K}$ mineral fertilizers combined also reduced potassium uptake and yield relative to $\mathrm{N}$ and $\mathrm{K}$ combined.
\end{abstract}

\section{Introduction}

The application of organic residues at or near to the surface as mulches or incorporated in the topsoil influences the behavior of soil water and temperature regime and supplies additional nutrients for crop growth. Soil physical and nutritional limitations are enhanced by marginal rain and temperatures due to more limited root growth [1] or transfer of ions from soil to roots [2]. Limitations of phosphate supply and un-sustainability of fossil-fuel-based fertilizers and their transport cost add to the significance of organic residues for agricultural use [3]. They also contain a large quantity of potassium [4]. A combined sludge from Mazandaran Mill (Iran) was used in this research.

Three different methods are used commercially to break down wood fiber (comprised principally of cellulosic com- pounds) mechanically or chemically to create wood pulp. Mechanical mills use stone discs (with or without heat) to grind the fibers. Kraft mills use sodium hydroxide and sodium sulphide to break down the fibers, while sulphite mills use calcium sulfite, magnesium sulfite, or ammonium sulfite [5]. Many mills use chlorine to bleach the paper, while other mills use hydrogen peroxide [6].

Solid wastes arising from above processes, commonly referred to as sludges, are available in three different classes. Primary or clarifier sludges are composed principally of wood fibers that have physically settled out of the wood/water slurry, or waste water, during initial virgin water treatment and are unsuitable for further processing. Secondary sludges arise from microbial decomposition used to remove suspended solids that were not removed during primary clarification of waste water. Secondary solids contain higher 
concentrations of nitrogen and phosphorous, added to the slurry mixtures to aid microbial activity, increase flocculation, and expedite the subsequent removal of suspended particles in the waste water. An additional class of paper mill sludges are the tertiary or deinking sludges, which are similar to primary sludges in fiber composition but also contain wastes filtered from the fiber stream during screening and deinking processes resulting from newsprint, magazine, and used-paper recycling [7].

Combination of charge distribution and stereochemical factors gives K-vermiculite surface complexes great stability and is the molecular basis for the term potassium fixation [8]. Desiccation during growing season by dry spells may cause that $\mathrm{K}$ rapidly disappears into the edge-situated interlattice sites. Formation of inner sphere Cs surface complexes is enhanced by drying sample at $65^{\circ} \mathrm{C}$ for 48 hours [8]. Interlattice $\mathrm{K}$ ions are held extremely preferentially with respect to other cations with illite and are also, therefore, largely nonexchangeable (in dilute electrolyte solutions). Along the edges; however, some $\mathrm{K}$ ions may be exchanged against, for example, $\mathrm{H}$ or $\mathrm{Ca}$, if the clay is brought in contact with solution of very low concentration (Bolt et al. [9]). Upon the intensification of agricultural production, the $\mathrm{K}$ supply becomes insufficient. Application of K fertilizer, however, gives only a meager response, because the increased concentration of $\mathrm{K}$ in the solution leads to entry of $\mathrm{K}$ in the vacated interlattice positions [9].

One may make use to some extent of the strong competition of $\mathrm{NH}_{4}$ ions for the interlattice sites. Application of the $\mathrm{NH}_{3}$ or $\mathrm{NH}_{4}$ salts (urea fertilizer), thus, gives (temporarily) $\mathrm{NH}_{4}$ fixation, suppressing the $\mathrm{K}$ fixation to some degree. The fixed $\mathrm{NH}_{4}$ is then gradually liberated throughout growing season and oxidized to nitrate [9]. NH4 in feeding solution increased outflow $\mathrm{K}$ concentration in an open system (flow through reactor) with soils of the site of experiment [10].

A balanced supply of nutrients is essential for optimal plant growth. Deficiency or excess in supply in one nutrient not only affects the uptake and utilization of that nutrient but also of others [11]. Plant nutrient ratios can be used to asses crop nutrient balance. For example, $\mathrm{K}: \mathrm{Ca}, \mathrm{K}: \mathrm{Mg}$ and $\mathrm{K}: \mathrm{Ca}+\mathrm{Mg}$ and other ratios are commonly used. When a nutrient ratio is optimal, optimum yield occurs unless some other limiting factor limits yield [2]. Because ions are taken up by plants in equivalents, it is important to be expressed as equivalent weights. If ions are expressed as percentages, over three times as much potassium as magnesium is required on a weight basis to obtain chemical equivalency. Therefore, meq/100 $\mathrm{g}$ of dry matter will be used as the primary means of expressing data in relation between monovalent potassium and divalent calcium and magnesium [12].

Both $\mathrm{Ca}$ and $\mathrm{Mg}$ compete with $\mathrm{K}$ for uptake; thus, soils high in one or both may require $\mathrm{K}$ fertilization for optimum $\mathrm{K}$ nutrition. $\mathrm{K}$ uptake would be reduced as $\mathrm{Ca}$ and $\mathrm{Mg}$ are increased; conversely, $\mathrm{Ca}$ and $\mathrm{Mg}$ would be reduced as $\mathrm{K}$ is increased. Thus, the $\mathrm{K}$ availability is somewhat more dependent on its concentration relative to $\mathrm{Ca}$ and $\mathrm{Mg}$ than on the total quantity of $\mathrm{K}$ present [2].
Mechanisms for the penetration of trace elements such as heavy metals in the soil are fairly simple as these small amounts will hardly influence the overall composition of the soil exchange complex. Obviously one then takes the major ion of the same valence as the minor one, and the distribution ratio for the minor cation is also constant during leaching. The transport of trace elements, thus, follows a linear exchange isotherm and moves in the soil with a step front, if it is introduced in that manner [9]. Major elements like $\mathrm{K}, \mathrm{Na}$, and $\mathrm{Ca}$ follow normally non-linear exchange isotherms with relative favor in exchange and leaching. Metal chelation (by organic amendments) is also important in soils because it increases the solubility of metal ions and affects many important physical, chemical, and biological processes including plant root uptake [13]. Watersoluble concentrations of many minerals such as iron are not sufficient to support plant growth in normal soil $\mathrm{pH}$. Various organic compounds offer various mole fractions of mineral species and availability to plants.

The objective of this research was to diagnose nutrients that affect wheat production in a high specific surface soil with illite as the dominant mineral in clay fraction and effects of sludge as mulch and incorporation on yield production.

\section{Materials and Methods}

2.1. Soil's Physical, Chemical, and Mineralogical Composition. A composite soil sample was obtained from the site of the experiment for physical, chemical, and mineralogical determinations. A standard digest technique for soil analysis [14] for carbon content percentage and total $\mathrm{N}$ applied (Table 1). Carbon content percentage was determined using a potassium dichromate method, $\mathrm{P}$ using a colorimetric method, $\mathrm{Ca}$ and $\mathrm{Mg}$ using an EDTA titration method, $\mathrm{N}$ by kjeltec, and $\mathrm{K}$ by flame photometry. Based on a general calibration for the $\mathrm{NH}_{4} \mathrm{OAc}-\mathrm{K}$ soil test [2, Chapter 9], the values for extracted potassium with these soils were highly greater than their suggested sufficiency levels $(>160 \mathrm{ppm}) . \mathrm{Ca}, \mathrm{Mg}$, and $\mathrm{K}$ were also determined in both soil paste and ammonium nitrate extracts to obtain normalized exchange isotherm using Gapon's selectivity coefficient for $\mathrm{K}-(\mathrm{Ca}+\mathrm{Mg})$ exchange. Phosphorous with Olsen's soil test was very high $(>20)$. Loess soils generally contain high quantities of $\mathrm{P}$ throughout their profile [2, Chapter 10]. $\mathrm{NO}^{-}$with 2 molar $\mathrm{KCl}$, was high $(18 \mathrm{ppm})$. Electrical conductivity for soil-saturated extract was less than 4 , and $\mathrm{pH}$ was about neutral (Table 1). Soil textural class was silty clay loam by hydrometer method [15]. Other determinations were organic carbon content, satura-percentage, total neutralizing value (\%TNV). Bulk density was obtained through core sampling (Table 1).

Mica (illite) was the dominant soil mineral with X-ray diffraction technique [16] using a D8-ADVANCE model. Other minerals were smectites, kaolinites, and chlorites in a descending order [17].

2.2. Chemical Composition of Paper-Mill Sludge. Chemical determinations of sludge material were undertaken for $\mathrm{C}$, 
TABLE 1: Chemical and physical analysis of the soil and combined sludge.

\begin{tabular}{|c|c|c|}
\hline Factors & Soil & $\begin{array}{l}\text { Combined } \\
\text { sludge }\end{array}$ \\
\hline Sand $(\%)$ & 10 & - \\
\hline Silt (\%) & 62 & - \\
\hline Clay $(\%)$ & 28 & - \\
\hline Specific surface $\left(\mathrm{m}^{2} / \mathrm{g}\right)$ & 130 & - \\
\hline Saturation moisture (\%) & 49 & 273 \\
\hline Dry bulk density $\left(\mathrm{g} \mathrm{cm}^{-3}\right)$ & 1.7 & 0.25 \\
\hline $\mathrm{EC}\left(\mathrm{dS} \mathrm{m} \mathrm{m}^{-1}\right)$ & 0.8 & 3.1 \\
\hline $\mathrm{pH}$ & 7.7 & 7.38 \\
\hline Neutral material (\%) & 5.5 & - \\
\hline Organic C (\%) & 1.43 & 22.4 \\
\hline $\mathrm{NO}_{3-} \mathrm{N}\left(\mathrm{mg} \mathrm{kg}^{-1}\right)$ & 18 & 600 \\
\hline Total N (\%) & 0.14 & 1.2 \\
\hline $\mathrm{NH}_{4-} \mathrm{N}\left(\mathrm{mg} \mathrm{kg}^{-1}\right)$ & 0.12 & 0.97 \\
\hline Available P $\left(\mathrm{mg} \mathrm{kg}^{-1}\right)$ & 7 & 22 \\
\hline Total P (\%) & - & 0.25 \\
\hline Extractable K (mg kg-1) & 380 & 540 \\
\hline Total K (\%) & - & 0.128 \\
\hline Extractable Ca (meq $\left.1^{-1}\right)$ & 6.6 & - \\
\hline Extractable $\mathrm{Na}\left(\right.$ meq $\left.\mathrm{l}^{-1}\right)$ & 1.3 & 12.6 \\
\hline Available $\mathrm{Ca}\left(\mathrm{mg} \mathrm{kg}^{-1}\right)$ & - & 1600 \\
\hline Total Ca (\%) & - & 0.412 \\
\hline Extractable $\mathrm{Mg}\left(\right.$ meq $\left.\mathrm{l}^{-1}\right)$ & 5.8 & - \\
\hline Available $\mathrm{Mg}\left(\mathrm{mg} \mathrm{kg}^{-1}\right)$ & - & 440 \\
\hline Total Mg $(\%)$ & - & 0.145 \\
\hline $\mathrm{CEC}\left(\mathrm{cmol} \mathrm{kg}^{-1}\right)$ & 20.3 & 82.6 \\
\hline Total Fe (mg kg-1) & - & 35 \\
\hline Total Mn $\left(\mathrm{mg} \mathrm{kg}^{-1}\right)$ & - & 22.8 \\
\hline Total Cu $\left(\mathrm{mg} \mathrm{kg}^{-1}\right)$ & - & 10.4 \\
\hline Total Zn $\left(\mathrm{mg} \mathrm{kg}^{-1}\right)$ & - & 15.7 \\
\hline Total Ni ( $\left.\mathrm{mg} \mathrm{kg}^{-1}\right)$ & - & 0.73 \\
\hline Total Cd $\left(\mathrm{mg} \mathrm{kg}^{-1}\right)$ & - & 0.42 \\
\hline Total $\mathrm{Pb}\left(\mathrm{mg} \mathrm{kg}^{-1}\right)$ & - & 4.7 \\
\hline Total Cr $\left(\mathrm{mg} \mathrm{kg}^{-1}\right)$ & - & 0.12 \\
\hline Total As $\left(\mathrm{mg} \mathrm{kg}^{-1}\right)$ & - & 4.5 \\
\hline Total Se $\left(\mathrm{mg} \mathrm{kg}^{-1}\right)$ & - & 2.5 \\
\hline Total Hg $\left(\mathrm{mg} \mathrm{kg}^{-1}\right)$ & - & 2.7 \\
\hline Total Mo $\left(\mathrm{mg} \mathrm{kg}^{-1}\right)$ & 一 & 6 \\
\hline
\end{tabular}

N, P, K, Ca, Mg, Fe, Mn, Cu, Zn, Ni, Ca, Pb, Cr, As, Se, $\mathrm{Hg}$, and Mo (Table 1). The method used a standard digest technique for plant analysis [18] for $\mathrm{N}, \mathrm{P}, \mathrm{K}, \mathrm{Ca}, \mathrm{Mg}$, and micronutrients and heavy metals. Micronutrients and heavy metals determined by atomic absorption. Total N, P, K, Ca, $\mathrm{Mg}, \mathrm{Fe}, \mathrm{Mn}, \mathrm{Cu}, \mathrm{Zn}, \mathrm{Ni}, \mathrm{Cd}, \mathrm{Pb}, \mathrm{Cr}, \mathrm{As}, \mathrm{Se}, \mathrm{Hg}$, and $\mathrm{Mo}$ for $50 \mathrm{t} /$ ha paper-mill sludge application were, respectively, $600,125,64,206,72.5,1.75,1.14,0.52,0.785,0.0365,0.021$, $0.235,0.006,0.225,0.125,0.135$, and $0.3 \mathrm{Kg} / \mathrm{ha}$ and for
100 t/ha were, respectively, twice as much. C/N ratio was 18.6 with negligible or no potential harm for plants through $\mathrm{N}$ immobilization. In terms of potentially toxic elements [19], application rates were well below maximum permissible limits for $\mathrm{Cu}, \mathrm{Zn}, \mathrm{Ni}, \mathrm{Cd}, \mathrm{Pb}, \mathrm{Cr}$, As, Se, Hg and Mo. $\mathrm{pH}$, EC, SP, and dry bulk density are also presented in Table 1.

The sludges obtained from Mazandaran wood and paper mill (Iran). In this mill, mechanical and chemical methods (both Kraft and sulfite processes) are used for pulping or wood fiber breakdown. The paper-mill sludge used for this research is a mixture of primary and secondary sludges (combined sludge).

2.3. Site and Treatments. The field trials were located in Rahmat Abad soil series on the estate of Gorgan university of Agricultural Sciences and Natural Resources (Pardis), Gorgan, Iran (approx. $37^{\circ} 45^{\prime} \mathrm{N}, 54^{\circ} 30^{\prime}$ E. altitude $13 \mathrm{~m}$ O.D.). The average annual rainfall (1991-2004) was $545.8 \mathrm{~mm}$, and mean air temperatures (1991-2004) were $8.5^{\circ} \mathrm{C}$ for January, $8^{\circ} \mathrm{C}$ for February.

Treatments were $50 \mathrm{t} / \mathrm{ha}\left(\mathrm{I}_{50}\right)$ and $100 \mathrm{t} / \mathrm{ha}\left(\mathrm{I}_{100}\right)$ papermill sludge incorporated with top soil (I treatments), $50 \mathrm{t} / \mathrm{ha}$ $\left(\mathrm{M}_{50}\right)$, and $100 \mathrm{t} / \mathrm{ha}\left(\mathrm{M}_{100}\right)$ paper-mill sludge applied as mulch ( $\mathrm{M}$ treatments). Applications were based on sludge dry weights. Other treatments were $\mathrm{N}_{0} \mathrm{P}_{0} \mathrm{~K}_{0}, \mathrm{~N}_{92} \mathrm{P}_{0} \mathrm{~K}_{0}$, $\mathrm{N}_{0} \mathrm{P}_{50} \mathrm{~K}_{0}, \quad \mathrm{~N}_{0} \mathrm{P}_{0} \mathrm{~K}_{83}, \quad \mathrm{~N}_{92} \mathrm{P}_{50} \mathrm{~K}_{0}, \quad \mathrm{~N}_{92} \mathrm{P}_{0} \mathrm{~K}_{83}, \quad \mathrm{~N}_{0} \mathrm{P}_{50} \mathrm{~K}_{83}$, and $\mathrm{N}_{92} \mathrm{P}_{50} \mathrm{~K}_{83}$. Subscripts are $\mathrm{Kg} / \mathrm{ha} \mathrm{N}$, P, and K. Fertilizer sources for $\mathrm{N}, \mathrm{P}$, and $\mathrm{K}$ were urea, triple superphosphate, and potassium sulfate. Triple superphosphate, potassium sulfate, and also one-third urea were incorporated to soils to a depth of $0.20 \mathrm{~m}$ in respective treatments immediately before drilling with a spade. One-third of urea was incorporated at tillering and the remaining one-third at heading using a manual furrower.

The land had been ploughed and disked before any treatments were applied. For the mulch treatments, the paper-mill sludge was applied uniformly over the land immediately after sowing manually. Where the sludge was to be incorporated (treatments $\mathrm{I}_{50}$ and $\mathrm{I}_{100}$ ), it was initially applied uniformly as a mulch and then incorporated to a depth of $0.2 \mathrm{~m}$ manually using a spade before drilling.

Seeds were treated with 5,6-dihydro-2-methyl-1,4-oxathiin-3-carboxamide fungicide powder (Vitavax, Uniroyal Chemical Co., USA) before drilling. Fenoxaprop-p-ethyl $5 \mathrm{~g} / \mathrm{L}$ herbicide (Puma Super, Bayer CropScience Inc., Canada) was applied at early March for curbing oat (Avena sativa). Other weeds such as turnip (Brassica napus), milk thistle (Silybum marianum) and bastard cabbage (Rapistrum rugosum) were removed later manually.

2.4. Experimental Design. A completely randomized block design was used with plot size $3 \mathrm{~m} \times 2 \mathrm{~m}$. Each treatment was replicated three times. Soil was a Typic Haploxerepts (Rahmat Abad soil series) of silty clay loam texture from a loess origin. Paper-mill sludge with a dry bulk density of $250 \mathrm{Kg} \mathrm{m}^{-3}$ and approximately $70 \%$ water content was applied on December 30, 2004 and laid on M treatments immediately after drilling or incorporated in the I treatments immediately before drilling at the same day both. Wheat 
(Triticum aestivum Var. Tajan) was drilled on 30 December, 2004 with seeds $0.02 \mathrm{~m}$ apart and $0.15 \mathrm{~m}$ between the rows, equivalent to 3300000 seeds per hectare.

2.5. Measurements. At harvest $1 \mathrm{~m}^{2}$ from the centre of each plot was harvested manually for determining fresh yield. A subsample was used for determining dry matter for grain and straw, harvest index, and yield components including stem length, head length, heads number per square meter, grains weight per head, and 1000 grain weight.

Chemical determinations of plant shoot material were undertaken for $\mathrm{N}, \mathrm{P}, \mathrm{K}, \mathrm{Ca}$, and $\mathrm{Mg}$ with a different subsample at harvest. The method used a standard digest technique [18], $\mathrm{N}$ was determined using Kjeltec, $\mathrm{P}$ using a colorimetric method, $\mathrm{K}$ by flame photometry, and $\mathrm{Ca}$ and $\mathrm{Mg}$ by an EDTA titration method.

The following chemical determinations were also made at harvest [14]: soil $\mathrm{pH}$, organic carbon content (using a potassium dichromate method), available $\mathrm{P}$ (from a sodium bicarbonate extract), $\mathrm{K}$ (using a $1 \mathrm{~N} \mathrm{NH}_{4} \mathrm{OAc}$ extractant), $\mathrm{Ca}$ and $\mathrm{Mg}$ (in soil-saturated paste extract). Soil available mineral-N $\left(\mathrm{NH}_{4}-\mathrm{N}+\mathrm{NO}_{3}-\mathrm{N}\right)$ was determined in a potassium chloride extract. The soil samples were taken randomly somewhere in plots from central location between two adjacent random rows from $0-0.20 \mathrm{~m}$ depth on June 5,1995 , three replicates per plot, and mixed. Data analysis used an ANOVA method with the SAS statistical package and regressions with Excel. Raw data are in Amini [20].

\section{Results}

3.1. Grain Yield and the Yield Parameters. Differences between treatments for dry grain yield, grains per head, grain weight per head, heads per square meter, and head length were significant by analysis of variance $(P<0.01)$ but were not significant for 1000 grain weight, stem length, and harvest indices $(P>0.05)$.

Dry grain yield for $\mathrm{N}_{92} \mathrm{P}_{0} \mathrm{~K}_{83}(4729.8 \mathrm{~kg} / \mathrm{ha})$ and high rate of mulch $(4825.3 \mathrm{~kg} / \mathrm{ha})$ were greater than other treatments (Table 2). Their differences with $\mathrm{N}_{0} \mathrm{P}_{0} \mathrm{~K}_{0} \quad(3207.7 \mathrm{~kg} / \mathrm{ha})$ were significant. Grain yield with incorporation treatments ( 2264.3 and $2158 \mathrm{~kg} /$ ha for $\mathrm{I}_{50}$ and $\mathrm{I}_{100}$, resp.) were less than other treatments, but differences with $\mathrm{N}_{0} \mathrm{P}_{0} \mathrm{~K}_{0}$ were not significant. All treatments increased significantly heads per square meter relative to $\mathrm{N}_{0} \mathrm{P}_{0} \mathrm{~K}_{0}$. It seems all additional sources of nutrients (notably N, P, and K) increased head density. Nutrient applications (such as starters) may be important for enhancing head density and early growth, because crop response to mobile and immobile nutrients may occur even in high-testing soils in cool and moist conditions [2, chapter 10] such as sub optimal topsoil temperatures in winter. Head densities per square meter were greatest with both incorporation treatments (410 and 398.3 for $I_{50}$ and $I_{100}$, resp.). A greater early growth and head density are not always suggesting a greater final yield.

Relative to other treatments, incorporations $\left(\mathrm{I}_{50}\right.$ and $\left.\mathrm{I}_{100}\right)$ returned minimum grains per head (19.9 and 19.26, resp.), grain weight per head ( 0.55 and $0.54 \mathrm{~g}$, resp.), head length (4.83 and $5.16 \mathrm{~cm}$ resp.), and 1000 grains weight (28 and
$28.76 \mathrm{~g}$ ). For $\mathrm{N}_{0} \mathrm{P}_{0} \mathrm{~K}_{0}$ grains per head, grain weight per head, head length, and 1000 grains weight were 33.66, $1.26 \mathrm{~g}$, $7.66 \mathrm{~cm}$, and $37.71 \mathrm{~g}$, respectively, and their differences with incorporations $\left(\mathrm{I}_{50}\right.$ and $\left.\mathrm{I}_{100}\right)$ were statistically significant. A low dry grain yield relative to $\mathrm{N}_{0} \mathrm{P}_{0} \mathrm{~K}_{0}$ with incorporation treatments is due to a reduced grain number, weight per head, head length, and 1000 grain weight despite greater heads per square meter. Maximum grains per head obtained by $\mathrm{N}_{92} \mathrm{P}_{0} \mathrm{~K}_{83}$ (37.46) and high rate of mulch (37.33) with no significant difference with $\mathrm{N}_{0} \mathrm{P}_{0} \mathrm{~K}_{0}$ (33.66) and other treatments. Maximum head length was with high rate of mulch $(9.6 \mathrm{~cm})$ with a significant difference with $\mathrm{N}_{0} \mathrm{P}_{0} \mathrm{~K}_{0}$ $(7.66 \mathrm{~cm})$. A high dry grain yield relative to $\mathrm{N}_{0} \mathrm{P}_{0} \mathrm{~K}_{0}$ with $\mathrm{N}_{92} \mathrm{P}_{0} \mathrm{~K}_{83}$ and high rate of mulch treatments is mainly due to greater heads per square meter. Heads per square meter were least with $\mathrm{N}_{0} \mathrm{P}_{0} \mathrm{~K}_{0}$. No effect on grain yield by low rate of mulch is possibly due to a low grain weight per head.

Stem lengths were greatest with $\mathrm{N}_{92} \mathrm{P}_{0} \mathrm{~K}_{83}(67.6 \mathrm{~cm})$ and $\mathrm{M}_{100}(68.3 \mathrm{~cm})$ with no significant difference with other treatments but incorporations. Total dry weights (grain + straw) were also greatest by $\mathrm{N}_{92} \mathrm{P}_{0} \mathrm{~K}_{83}$ and high rate of mulch applications but with $\mathrm{N}_{92} \mathrm{P}_{50} \mathrm{~K}_{83}$ was less than $\mathrm{N}_{92} \mathrm{P}_{0} \mathrm{~K}_{83}$.

The least harvest indices were with both rates of incorporations. Harvest indices for $\mathrm{N}_{92} \mathrm{P}_{0} \mathrm{~K}_{83}$ and mulch treatments were not significantly different relative to other remaining treatments due to concurrent straw and grain yield increase. Irrespective of statistics, harvest indices were greatest with $\mathrm{N}_{0} \mathrm{P}_{50} \mathrm{~K}_{0}, \mathrm{~N}_{92} \mathrm{P}_{50} \mathrm{~K}_{0}, \mathrm{~N}_{0} \mathrm{P}_{50} \mathrm{~K}_{83}$, and $\mathrm{N}_{92} \mathrm{P}_{50} \mathrm{~K}_{83}$ treatments.

3.2. Shoot Tissue Nutrient Concentration and Uptake, Soil Organic Carbon, Soil Nutrient Concentration, and $\mathrm{Ca}+$ $\mathrm{Mg})$ : K Ratios for Plant and Soil at Harvest. N, K, Ca, and Mg concentrations in shoot tissue at harvest were significantly different between treatments by analysis of variance $(P<$ 0.01). $P$ concentration was not significantly different $(P<$ 0.05). N, P, K, Ca, and Mg plant shoot uptakes at harvest were significantly different between treatments by analysis of variance $(P<0.01)$.

Soil $\mathrm{NO}_{3}^{-}, \mathrm{NH}_{4}^{+}$, organic $\mathrm{C}$, total $\mathrm{N}$, available $\mathrm{P}$, extractable $\mathrm{K}$, and $\mathrm{C} / \mathrm{N}$ ratio were significantly different between treatments at harvest by analysis of variance $(P<$ 0.01). Soil extractable $\mathrm{Ca}$ and $\mathrm{Mg}, \mathrm{EC}$, and $\mathrm{pH}$ were not significantly different between treatments $(P>0.05)$. $(\mathrm{Ca}+$ $\mathrm{Mg}): \mathrm{K}$ ratios were significantly different among treatments by analysis of variance $(P<0.01)$ for plant tissue but not significantly different for soil $(P>0.05)$.

\subsection{Shoot Tissue N Concentrations, Uptake, and Soil N Con-} centration. Percentage mean treatment tissue $\mathrm{N}$ concentrations with low $(0.451 \%)$ and high rates of sludge incorporation $(0.47 \%)$ and also $\mathrm{N}_{0} \mathrm{P}_{50} \mathrm{~K}_{0}(0.549 \%)$ were significantly less than other treatments (Table 3 ). Dry grain yield and total dry matter at harvest (Table 2) and the $\mathrm{N}$ uptake (Table 4) were less than other treatments with low and high rates of incorporations (35.53 and $36.60 \mathrm{Kg} / \mathrm{ha} \mathrm{N}$ uptake, resp.), but they were greater than other treatments with the high rate of mulch $(90.46 \mathrm{Kg} /$ ha for $\mathrm{N}$ uptake). Despite high soil nitrate concentration with $\mathrm{N}_{92} \mathrm{P}_{0} \mathrm{~K}_{0}$, yield and tissue $\mathrm{N}$ concentrations were not significantly different with 
TABLE 2: Harvest index, grain components (stem length, head length, heads per square meter, grains weight per head, 1000 grains weight), grain yield, and the total shoot dry matter.

\begin{tabular}{|c|c|c|c|c|c|c|c|c|c|}
\hline $\begin{array}{l}\text { Shoot dry } \\
\text { treatment }\end{array}$ & $\begin{array}{c}\text { Harvest } \\
\text { index }\end{array}$ & $\begin{array}{l}\text { Stem } \\
\text { length } \\
(\mathrm{cm})\end{array}$ & $\begin{array}{l}\text { Head } \\
\text { length } \\
(\mathrm{cm})\end{array}$ & $\begin{array}{l}\text { Grain } \\
\text { heads per } \\
\text { square } \\
\text { meter }\end{array}$ & $\begin{array}{c}\text { Grain } \\
\text { weight per } \\
\text { head }(\mathrm{g})\end{array}$ & $\begin{array}{l}\text { Grains per } \\
\text { head }\end{array}$ & $\begin{array}{l}\text { 1000-grain } \\
\text { weight }(\mathrm{g})\end{array}$ & $\begin{array}{c}\text { Dry grain } \\
\text { yield } \\
\text { (Kg/ha) }\end{array}$ & $\begin{array}{c}\text { Total } \\
\text { shoot dry } \\
\text { matter } \\
(\mathrm{Kg} / \mathrm{ha})\end{array}$ \\
\hline $\mathrm{N}_{92} \mathrm{P}_{0} \mathrm{~K}_{0}$ & $38.46^{\mathrm{a}}$ & $61.6^{\mathrm{abcd}}$ & $8.16^{\mathrm{ab}}$ & $313.3^{\mathrm{d}}$ & $1.1^{\mathrm{ab}}$ & $32.33^{\mathrm{ab}}$ & $34.58^{\mathrm{ab}}$ & $3465.3^{\text {bcde }}$ & $9033^{\text {cd }}$ \\
\hline $\mathrm{N}_{0} \mathrm{P}_{50} \mathrm{~K}_{0}$ & $42.83^{\mathrm{a}}$ & $62.3^{\mathrm{abcd}}$ & $7.5^{\mathrm{b}}$ & $360^{\mathrm{bc}}$ & $1.14^{\mathrm{ab}}$ & $32.2^{\mathrm{ab}}$ & $35.66^{\mathrm{a}}$ & $4105.3^{\mathrm{abcd}}$ & $9783^{\mathrm{cd}}$ \\
\hline $\mathrm{N}_{0} \mathrm{P}_{0} \mathrm{~K}_{83}$ & $39.4^{\mathrm{a}}$ & $63.3^{\mathrm{abcd}}$ & $7.66^{\mathrm{ab}}$ & $339.6^{\mathrm{cd}}$ & $1.06^{\mathrm{ab}}$ & $27.26^{\mathrm{bc}}$ & $39.16^{\mathrm{a}}$ & $3630.7^{\mathrm{abcd}}$ & $9233^{\mathrm{cd}}$ \\
\hline $\mathrm{N}_{92} \mathrm{P}_{50} \mathrm{~K}_{0}$ & $40.41^{\mathrm{a}}$ & $65.5^{\mathrm{ab}}$ & $8.66^{\mathrm{ab}}$ & $360.3^{b c}$ & $1.18^{\mathrm{ab}}$ & $35.46^{\mathrm{ab}}$ & $33.33^{\mathrm{abc}}$ & $4262.8^{\mathrm{abcd}}$ & $10500^{c}$ \\
\hline $\mathrm{N}_{92} \mathrm{P}_{0} \mathrm{~K}_{83}$ & $35.16^{\mathrm{abc}}$ & $67.6^{\mathrm{ab}}$ & $8.66^{\mathrm{ab}}$ & $359.6^{\mathrm{bc}}$ & $1.31^{\mathrm{a}}$ & $37.46^{\mathrm{a}}$ & $35.17^{\mathrm{ab}}$ & $4729.8^{\mathrm{ab}}$ & $13450^{\mathrm{a}}$ \\
\hline $\mathrm{N}_{0} \mathrm{P}_{50} \mathrm{~K}_{83}$ & $41.4^{\mathrm{a}}$ & $64^{\mathrm{abc}}$ & $8.16^{\mathrm{ab}}$ & $353.67^{c d}$ & $1.1^{\mathrm{ab}}$ & $32.1^{\mathrm{ab}}$ & $34.56^{\mathrm{ab}}$ & $3957.3^{\mathrm{abcd}}$ & $9600^{\mathrm{cd}}$ \\
\hline $\mathrm{N}_{92} \mathrm{P}_{50} \mathrm{~K}_{83}$ & $40.67^{a}$ & $65.5^{\mathrm{ab}}$ & $8.5^{\mathrm{ab}}$ & $355^{\mathrm{c}}$ & $1.24^{\mathrm{a}}$ & $36.26^{\mathrm{ab}}$ & $34.13^{\mathrm{abc}}$ & $4401.6^{\mathrm{abc}}$ & $10800^{\mathrm{bc}}$ \\
\hline $\mathrm{I}_{50}$ & $28.58^{c}$ & $56.3^{\mathrm{d}}$ & $4.83^{\mathrm{c}}$ & $410^{\mathrm{a}}$ & $0.55^{\mathrm{c}}$ & $19.9^{c}$ & $28^{\mathrm{c}}$ & $2264.3^{\mathrm{ef}}$ & $7883^{\mathrm{d}}$ \\
\hline $\mathrm{M}_{50}$ & $36.56^{\mathrm{abc}}$ & $60.3^{\mathrm{bcd}}$ & $7.8^{\mathrm{ab}}$ & $333.3^{\mathrm{cd}}$ & $0.92^{\mathrm{b}}$ & $27.23^{b c}$ & $34^{\mathrm{abc}}$ & $3076.1^{\mathrm{def}}$ & $8517^{\mathrm{cd}}$ \\
\hline $\mathrm{I}_{100}$ & $27.75^{c}$ & $56.6^{\mathrm{cd}}$ & $5.16^{\mathrm{c}}$ & $398.3^{\mathrm{ab}}$ & $0.54^{\mathrm{c}}$ & $19.26^{c}$ & $28.76^{\mathrm{bc}}$ & $2158^{f}$ & $7783^{d}$ \\
\hline $\mathrm{M}_{100}$ & $36.49^{\mathrm{abc}}$ & $68.3^{\mathrm{a}}$ & $9.6^{\mathrm{a}}$ & $373^{\mathrm{abc}}$ & $1.29^{\mathrm{a}}$ & $37.33^{\mathrm{a}}$ & $34.66^{\mathrm{ab}}$ & $4825.3^{\mathrm{a}}$ & $13233^{\mathrm{ab}}$ \\
\hline $\mathrm{N}_{0} \mathrm{P}_{0} \mathrm{~K}_{0}$ & $37.92^{\mathrm{ab}}$ & $61.3^{\mathrm{abcd}}$ & $7.66^{\mathrm{ab}}$ & $254^{\mathrm{e}}$ & $1.26^{\mathrm{a}}$ & $33.66^{\mathrm{ab}}$ & $37.71^{\mathrm{a}}$ & $3207.7^{\text {cdef }}$ & $8450^{\mathrm{cd}}$ \\
\hline
\end{tabular}

Means within the same column followed by the same letter are not statistically different at $P=0.05$ (Fisher's LSD).

$\mathrm{N}_{0} \mathrm{P}_{0} \mathrm{~K}_{0}$. Urea fertilizer application lowered percentage of tissue $\mathrm{N}$ concentration with $\mathrm{N}_{92} \mathrm{P}_{0} \mathrm{~K}_{83}$ treatment (0.518) relative to all other urea containing treatments through dilution effect by increasing yield. In K-fixing soils, urea may increase fertilizer potassium availability for plants through ammonium release and competition for $\mathrm{K}$ fixation. This may lead to increased tissue potassium concentration and uptake. Soil nitrate concentration (Table 5) may not be closely correlated with tissue nitrate concentration due to dilution effect; increased plant uptake may also diminish soil concentration. Soil nitrate concentrations, with both rates of incorporation and also mulch treatments, $\mathrm{N}_{0} \mathrm{P}_{50} \mathrm{~K}_{0}$ and $\mathrm{N}_{0} \mathrm{P}_{0} \mathrm{~K}_{0}$ were significantly less than $\mathrm{N}_{0} \mathrm{P}_{0} \mathrm{~K}_{0}$ and with $\mathrm{N}_{92} \mathrm{P}_{0} \mathrm{~K}_{0}$ and $\mathrm{N}_{92} \mathrm{P}_{50} \mathrm{~K}_{83}$ significantly greater than $\mathrm{N}_{0} \mathrm{P}_{0} \mathrm{~K}_{0}$. Greatest nitrate concentrations occurred with nitrogenbearing treatments.

The ammonium from urea fertilizer application is converted into nitrite by Nitrosomonas autotrophic bacteria and then promptly to nitrate by autotrophic nitrobacteria activities under aerobic conditions. These bacteria obtain energy through nitrogen oxidation and carbon from the atmospheric carbon dioxide. The dominant soil $\mathrm{N}$ mineral form would be expected to be nitrate at harvest (soil sampling time), a long time after fertilization (Table 5).

3.4. Soil Organic Carbon. Soil organic $C$ content with all rates of mulch and incorporation treatments was significantly greater than other treatments at harvest (Table 5), indicating that paper-mill sludge was not yet completely decomposed at harvest. Soil organic $\mathrm{C}$ with low and high rates of mulch were less than low and high rates of sludge incorporation, respectively, which shows a more rapid decomposition by mulch application. This increases total $\mathrm{N}$ release and other elements in soil including $\mathrm{K}, \mathrm{Ca}$, and $\mathrm{Mg}$ with mulch. Soil organic $\mathrm{C}$ with fertilizer treatments was not significantly different with $\mathrm{N}_{0} \mathrm{P}_{0} \mathrm{~K}_{0}$. $\mathrm{EC}_{s}$ (ds/m) were less than 0.7 by all treatments.

3.5. Shoot Tissue Potassium Concentration, Uptake, and Soil Extractable Potassium Concentration. Incorporation treatments with least tissue potassium concentrations are placed in $\mathrm{f}$ statistical group in Table 3 and are significantly different with $\mathrm{N}_{0} \mathrm{P}_{0} \mathrm{~K}_{0}$. $\mathrm{N}_{92} \mathrm{P}_{0} \mathrm{~K}_{83}$ and $\mathrm{N}_{0} \mathrm{P}_{50} \mathrm{~K}_{83}$ treatments with the greatest tissue potassium concentrations are placed in statistical group a in Table 3 .

Potassium plant tissue concentration for high rate of mulch application is placed in b statistical group and is significantly greater than $\mathrm{N}_{0} \mathrm{P}_{0} \mathrm{~K}_{0}$. Potassium uptake by this treatment is in statistical group a, due to high yield production. $\mathrm{K}$ uptake with $\mathrm{N}_{92} \mathrm{P}_{0} \mathrm{~K}_{83}$ was also significantly greater than other treatments (Table 4). Potassium uptake by $\mathrm{N}_{92} \mathrm{P}_{50} \mathrm{~K}_{83}$ was significantly less than $\mathrm{N}_{92} \mathrm{P}_{0} \mathrm{~K}_{83}$. Least $\mathrm{K}$ uptakes occurred with both rates of sludge incorporation.

$1 \mathrm{~N} \mathrm{NH}_{4} \mathrm{OAc}$ soil potassium concentrations by both incorporation treatments were significantly less than other treatments. The greatest soil extractable potassium concentrations were with $\mathrm{N}_{92} \mathrm{P}_{0} \mathrm{~K}_{83}$ and high rate of mulch treatments. Their differences with $\mathrm{N}_{0} \mathrm{P}_{0} \mathrm{~K}_{0}$ treatment were not statistically significant however (Table 5). Plant tissue potassium concentrations and uptakes were less with $\mathrm{N}_{0} \mathrm{P}_{0} \mathrm{~K}_{0}$ however. Lack of correlation between soil potassium concentration and plant potassium uptake suggests $1 \mathrm{~N} \mathrm{NH}_{4} \mathrm{OAc}$ is not suitable for extracting plant-available potassium from soils characterized by a great specific surface and illite dominance in clay fraction. This was elaborated upon in Amini [20].

3.6. Normalized Exchange Isotherm. Normalized exchange isotherm was constructed (Figure 1) using Gapon's selectivity coefficient for $\mathrm{K}-(\mathrm{Ca}+\mathrm{Mg})$ exchange [9]. $\mathrm{K}_{\mathrm{G}}$ was $16.58(\mathrm{~L} / \mathrm{mole})^{0.5}$ for soils of the experimental site with illite 
TABLE 3: Tissue nutrient concentrations for shoot at harvest (\%).

\begin{tabular}{|c|c|c|c|c|c|}
\hline Treatment & $\mathrm{N}$ & $\mathrm{P}$ & K & $\mathrm{Ca}$ & $\mathrm{Mg}$ \\
\hline $\mathrm{N}_{92} \mathrm{P}_{0} \mathrm{~K}_{0}$ & $0.56^{c}$ & $0.204^{\mathrm{d}}$ & $0.391^{\mathrm{d}}$ & $0.12^{\mathrm{d}}$ & $0.14^{\mathrm{a}}$ \\
\hline $\mathrm{N}_{0} \mathrm{P}_{50} \mathrm{~K}_{0}$ & $0.453^{\mathrm{e}}$ & $0.253^{\mathrm{a}}$ & $0.343^{\mathrm{e}}$ & $0.136^{b c}$ & $0.11^{b c}$ \\
\hline $\mathrm{N}_{0} \mathrm{P}_{0} \mathrm{~K}_{83}$ & $0.552^{\mathrm{c}}$ & $0.223^{\mathrm{bcd}}$ & $0.458^{\mathrm{c}}$ & $0.125^{\mathrm{cd}}$ & $0.105^{\mathrm{bc}}$ \\
\hline $\mathrm{N}_{92} \mathrm{P}_{50} \mathrm{~K}_{0}$ & $0.593^{\mathrm{b}}$ & $0.219^{\mathrm{bcd}}$ & $0.351^{\mathrm{e}}$ & $0.125^{\mathrm{cd}}$ & $0.115^{\mathrm{bc}}$ \\
\hline $\mathrm{N}_{92} \mathrm{P}_{0} \mathrm{~K}_{83}$ & $0.518^{\mathrm{d}}$ & $0.245^{\mathrm{ab}}$ & $0.707^{\mathrm{a}}$ & $0.141^{\mathrm{b}}$ & $0.155^{\mathrm{a}}$ \\
\hline $\mathrm{N}_{0} \mathrm{P}_{50} \mathrm{~K}_{83}$ & $0.602^{\mathrm{b}}$ & $0.232^{\mathrm{abc}}$ & $0.72^{\mathrm{a}}$ & $0.161^{\mathrm{a}}$ & $0.155^{\mathrm{a}}$ \\
\hline $\mathrm{N}_{92} \mathrm{P}_{50} \mathrm{~K}_{83}$ & $0.552^{\mathrm{c}}$ & $0.229^{\mathrm{abcd}}$ & $0.366^{\text {de }}$ & $0.131^{\mathrm{bcd}}$ & $0.12^{\mathrm{b}}$ \\
\hline $\mathrm{I}_{50}$ & $0.451^{\mathrm{e}}$ & $0.233^{\mathrm{abc}}$ & $0.281^{\mathrm{f}}$ & $0.135^{\mathrm{bc}}$ & $0.105^{\mathrm{bc}}$ \\
\hline $\mathrm{M}_{50}$ & $0.519^{\mathrm{d}}$ & $0.222^{\mathrm{bcd}}$ & $0.365^{\mathrm{de}}$ & $0.135^{\mathrm{bc}}$ & $0.105^{\mathrm{bc}}$ \\
\hline $\mathrm{I}_{100}$ & $0.47^{\mathrm{e}}$ & $0.236^{\mathrm{abc}}$ & $0.292^{\mathrm{f}}$ & $0.135^{\mathrm{bc}}$ & $0.12^{\mathrm{b}}$ \\
\hline $\mathrm{M}_{100}$ & $0.68^{\mathrm{a}}$ & $0.24^{\mathrm{ab}}$ & $0.628^{\mathrm{b}}$ & $0.14^{\mathrm{b}}$ & $0.12^{\mathrm{b}}$ \\
\hline $\mathrm{N}_{0} \mathrm{P}_{0} \mathrm{~K}_{0}$ & $0.549^{c}$ & $0.212^{\mathrm{cd}}$ & $0.38^{\mathrm{de}}$ & $0.12^{\mathrm{d}}$ & $0.12^{\mathrm{b}}$ \\
\hline
\end{tabular}

Means within the same column followed by the same letter are not statistically different at $P=0.05$ (Fisher's LSD).

TABle 4: Nutrient uptakes for shoot at harvest (Kg/ha).

\begin{tabular}{|c|c|c|c|c|c|}
\hline Treatment & $\mathrm{N}$ & $\mathrm{P}$ & $\mathrm{K}$ & $\mathrm{Ca}$ & $\mathrm{Mg}$ \\
\hline $\mathrm{N}_{92} \mathrm{P}_{0} \mathrm{~K}_{0}$ & $50.59^{\text {cde }}$ & $18.46^{c}$ & $35.37^{\mathrm{cd}}$ & $10.75^{\mathrm{cd}}$ & $12.64^{\text {bcde }}$ \\
\hline $\mathrm{N}_{0} \mathrm{P}_{50} \mathrm{~K}_{0}$ & $44.27^{\mathrm{ef}}$ & $24.8^{\mathrm{b}}$ & $33.68^{\text {cde }}$ & $13.34^{\mathrm{bcd}}$ & $10.76^{\mathrm{defg}}$ \\
\hline $\mathrm{N}_{0} \mathrm{P}_{0} \mathrm{~K}_{83}$ & $50.96^{\text {cde }}$ & $20.56^{b c}$ & $42.3^{c}$ & $11.57^{\mathrm{cd}}$ & $9.63^{\mathrm{defg}}$ \\
\hline $\mathrm{N}_{92} \mathrm{P}_{50} \mathrm{~K}_{0}$ & $62.26^{\mathrm{bc}}$ & $23.06^{b c}$ & $36.82^{c}$ & $13.17^{\mathrm{bcd}}$ & $12.09^{\text {cdef }}$ \\
\hline $\mathrm{N}_{92} \mathrm{P}_{0} \mathrm{~K}_{83}$ & $69.67^{\mathrm{b}}$ & $32.94^{\mathrm{a}}$ & $95.03^{\mathrm{a}}$ & $19.03^{\mathrm{a}}$ & $20.86^{\mathrm{a}}$ \\
\hline $\mathrm{N}_{0} \mathrm{P}_{50} \mathrm{~K}_{83}$ & $57.72^{\text {bcd }}$ & $22.27^{b c}$ & $70.31^{\mathrm{b}}$ & $15.54^{\mathrm{ab}}$ & $14.9^{\mathrm{bc}}$ \\
\hline $\mathrm{N}_{92} \mathrm{P}_{50} \mathrm{~K}_{83}$ & $59.58^{\mathrm{bc}}$ & $24.7^{\mathrm{b}}$ & $39.55^{c}$ & $14.24^{\mathrm{bc}}$ & $12.94^{\mathrm{bcd}}$ \\
\hline $\mathrm{I}_{50}$ & $35.53^{\mathrm{f}}$ & $18.4^{\mathrm{c}}$ & $22.13^{\mathrm{e}}$ & $10.64^{\mathrm{cd}}$ & $8.11^{\mathrm{g}}$ \\
\hline $\mathrm{M}_{50}$ & $44.13^{\mathrm{ef}}$ & $19^{\mathrm{bc}}$ & $31.01^{\text {cde }}$ & $11.54^{\mathrm{cd}}$ & $9.07^{\mathrm{fg}}$ \\
\hline $\mathrm{I}_{100}$ & $36.6^{\mathrm{f}}$ & $18.38^{\mathrm{c}}$ & $22.74^{\mathrm{de}}$ & $10.5^{\mathrm{cd}}$ & $9.34^{\mathrm{efg}}$ \\
\hline $\mathrm{M}_{100}$ & $90.46^{\mathrm{a}}$ & $31.73^{\mathrm{a}}$ & $83.41^{\mathrm{a}}$ & $18.49^{\mathrm{a}}$ & $15.81^{\mathrm{b}}$ \\
\hline $\mathrm{N}_{0} \mathrm{P}_{0} \mathrm{~K}_{0}$ & $46.4^{\mathrm{def}}$ & $17.91^{\mathrm{c}}$ & $31.35^{\text {cde }}$ & $10.34^{\mathrm{d}}$ & $10.14^{\text {defg }}$ \\
\hline
\end{tabular}

Means within the same column followed by the same letter are not statistically different at $P=0.05$ (Fisher's LSD).

TABLE 5: Soil nutrient concentrations at harvest.

\begin{tabular}{|c|c|c|c|c|c|c|c|c|c|c|c|}
\hline Treatment & $\begin{array}{l}\mathrm{NO}_{3-} \mathrm{N} \\
\left(\mathrm{mg} \mathrm{kg}^{-1}\right)\end{array}$ & $\begin{array}{l}\mathrm{NH}_{4-} \mathrm{N} \\
\left(\mathrm{mg} \mathrm{kg}^{-1}\right)\end{array}$ & $\begin{array}{l}\text { Organic C } \\
(\%)\end{array}$ & $\begin{array}{l}\text { Total N } \\
(\%)\end{array}$ & $\begin{array}{l}\text { Avai. P } \\
\left(\mathrm{mg} \mathrm{kg}^{-1}\right)\end{array}$ & $\begin{array}{l}\text { Avai. K } \\
\left(\mathrm{mg} \mathrm{kg}^{-1}\right)\end{array}$ & $\begin{array}{l}\text { Ext. Ca } \\
\left(\text { meq }^{-1}\right)\end{array}$ & $\begin{array}{l}\text { Ext. Mg } \\
\left(\text { meq } 1^{-1}\right)\end{array}$ & $\begin{array}{l}\mathrm{EC}(\mathrm{dS} \\
\left.\mathrm{m}^{-1}\right)\end{array}$ & $\mathrm{pH}$ & $\mathrm{C} / \mathrm{N}$ \\
\hline $\mathrm{N}_{92} \mathrm{P}_{0} \mathrm{~K}_{0}$ & $38.8^{\mathrm{a}}$ & $0.1^{\mathrm{d}}$ & $1.25^{\mathrm{e}}$ & $0.12^{\mathrm{e}}$ & $18.06^{\mathrm{d}}$ & $380^{\mathrm{b}}$ & $5.1^{\mathrm{a}}$ & $4.1^{\mathrm{a}}$ & $0.46^{\mathrm{b}}$ & $7.55^{\text {abcd }}$ & $10.41^{\mathrm{ab}}$ \\
\hline $\mathrm{N}_{0} \mathrm{P}_{50} \mathrm{~K}_{0}$ & $7.66^{\mathrm{d}}$ & $0.12^{\mathrm{d}}$ & $1.23^{\mathrm{e}}$ & $0.12^{\mathrm{e}}$ & $24^{c}$ & $385.6^{\mathrm{ab}}$ & $5.23^{\mathrm{a}}$ & $4.3^{\mathrm{a}}$ & $0.58^{\mathrm{ab}}$ & $7.54^{\mathrm{abcd}}$ & $10.26^{\mathrm{ab}}$ \\
\hline $\mathrm{N}_{0} \mathrm{P}_{0} \mathrm{~K}_{83}$ & $18^{c}$ & $0.15^{c}$ & $1.31^{\mathrm{de}}$ & $0.13^{\mathrm{e}}$ & $15.7^{\mathrm{d}}$ & $392^{\mathrm{ab}}$ & $4.8^{\mathrm{a}}$ & $3.8^{\mathrm{a}}$ & $0.58^{\mathrm{ab}}$ & $7.45^{\mathrm{cd}}$ & $10.07^{\mathrm{ab}}$ \\
\hline $\mathrm{N}_{92} \mathrm{P}_{50} \mathrm{~K}_{0}$ & $30.6^{\mathrm{b}}$ & $0.1^{\mathrm{d}}$ & $1.17^{\mathrm{e}}$ & $0.12^{\mathrm{e}}$ & $27.3^{\mathrm{bc}}$ & $380^{\mathrm{b}}$ & $5.2^{\mathrm{a}}$ & $4.2^{\mathrm{a}}$ & $0.67^{\mathrm{a}}$ & $7.55^{\mathrm{abcd}}$ & $9.77^{\mathrm{bcd}}$ \\
\hline $\mathrm{N}_{92} \mathrm{P}_{0} \mathrm{~K}_{83}$ & $22^{c}$ & $0.12^{\mathrm{d}}$ & $1.19^{\mathrm{e}}$ & $0.13^{\mathrm{e}}$ & $14.9^{\mathrm{d}}$ & $407.6^{\mathrm{a}}$ & $5.1^{\mathrm{a}}$ & $4.2^{\mathrm{a}}$ & $0.59^{\mathrm{ab}}$ & $7.75^{\mathrm{a}}$ & $9.15^{\mathrm{e}}$ \\
\hline $\mathrm{N}_{0} \mathrm{P}_{50} \mathrm{~K}_{83}$ & $18^{\mathrm{c}}$ & $0.15^{c}$ & $1.37^{\mathrm{de}}$ & $0.14^{\mathrm{e}}$ & $35.6^{\mathrm{a}}$ & $387.3^{\mathrm{ab}}$ & $5.33^{\mathrm{a}}$ & $4.3^{\mathrm{a}}$ & $0.51^{\mathrm{ab}}$ & $7.62^{\mathrm{abc}}$ & $9.8^{\text {bcde }}$ \\
\hline $\mathrm{N}_{92} \mathrm{P}_{50} \mathrm{~K}_{83}$ & $36^{\mathrm{a}}$ & $0.15^{\mathrm{c}}$ & $1.3^{\mathrm{de}}$ & $0.14^{\mathrm{e}}$ & $27^{\mathrm{bc}}$ & $394^{\mathrm{ab}}$ & $5^{\mathrm{a}}$ & $4^{\mathrm{a}}$ & $0.47^{\mathrm{b}}$ & $7.69^{\mathrm{ab}}$ & $9.27^{\mathrm{de}}$ \\
\hline $\mathrm{I}_{50}$ & $7.33^{\mathrm{d}}$ & $0.22^{\mathrm{b}}$ & $2.39^{\mathrm{b}}$ & $0.23^{\mathrm{b}}$ & $17.36^{\mathrm{d}}$ & $340.3^{c}$ & $5.66^{\mathrm{a}}$ & $4.96^{\mathrm{a}}$ & $0.51^{\mathrm{ab}}$ & $7.48^{\mathrm{bcd}}$ & $10.41^{\mathrm{ab}}$ \\
\hline $\mathrm{M}_{50}$ & $9.3^{\mathrm{d}}$ & $0.12^{\mathrm{d}}$ & $1.48^{\mathrm{d}}$ & $0.16^{\mathrm{d}}$ & $17.23^{\mathrm{d}}$ & $383.6^{\mathrm{ab}}$ & $5.5^{\mathrm{a}}$ & $4.73^{\mathrm{a}}$ & $0.45^{\mathrm{b}}$ & $7.57^{\mathrm{abc}}$ & $9.26^{\mathrm{de}}$ \\
\hline $\mathrm{I}_{100}$ & $9.3^{\mathrm{d}}$ & $0.27^{\mathrm{a}}$ & $2.86^{\mathrm{a}}$ & $0.27^{\mathrm{a}}$ & $17.1^{\mathrm{d}}$ & $346.6 \mathrm{c}$ & $6.16^{\mathrm{a}}$ & $5.2^{\mathrm{a}}$ & $0.59^{\mathrm{ab}}$ & $7.52^{\mathrm{abcd}}$ & $10.6^{\mathrm{a}}$ \\
\hline $\mathrm{M}_{100}$ & $10^{\mathrm{d}}$ & $0.2^{\mathrm{b}}$ & $1.81^{\mathrm{c}}$ & $0.19^{c}$ & $30.1^{\mathrm{ab}}$ & $405.3^{\mathrm{ab}}$ & $6^{a}$ & $4.8^{\mathrm{a}}$ & $0.66^{\mathrm{a}}$ & $7.5^{\mathrm{bcd}}$ & $9.52^{\text {cde }}$ \\
\hline $\mathrm{N}_{0} \mathrm{P}_{0} \mathrm{~K}_{0}$ & $10.33^{\mathrm{d}}$ & $0.1^{\mathrm{d}}$ & $1.2^{\mathrm{e}}$ & $0.12^{\mathrm{e}}$ & $16.9^{\mathrm{d}}$ & $393.3^{\mathrm{ab}}$ & $4.66^{\mathrm{a}}$ & $3.5^{\mathrm{a}}$ & $0.46^{\mathrm{b}}$ & $7.33^{d}$ & $10^{\mathrm{abcd}}$ \\
\hline
\end{tabular}

Means within the same column followed by the same letter are not statistically different at $P=0.05$ (Fisher's LSD). 
dominance in clay fraction. This ratio is generally less than unity for most minerals and soils [21]. Potassium is held apparently with greater preference relative to divalent cations in close vicinity of colloids in soils exhibiting high specific surface and truncated diffuse double layers. The $\mathrm{K}$ ion fits snugly into the hexagonal cavity that is built into layer silicate surfaces and becomes trapped or fixed in a nonexchangeable form. Exchange equations cannot adequately quantify this kind of behavior [22]. This may be less evident when $\mathrm{N}$ and $\mathrm{K}$ fertilizers are used combined or with sludge containing $\mathrm{N}$ and $\mathrm{K}$ because, according to Bolt et al. [9], $\mathrm{NH}_{4}$ is fixed roughly to the same extent as $\mathrm{K}$ ions with illites, suppressing the $\mathrm{K}$ fixation to some degree.

3.7. Shoot Tissue Phosphorous Concentration, Uptake, and Soil Phosphorous Concentration. The greatest phosphorous tissue concentrations relative to other treatments occurred with $\mathrm{N}_{0} \mathrm{P}_{50} \mathrm{~K}_{0}, \mathrm{~N}_{92} \mathrm{P}_{0} \mathrm{~K}_{83}$, and high rate of mulch (Table 2). The greatest phosphorous plant uptakes obtained with $\mathrm{N}_{92} \mathrm{P}_{0} \mathrm{~K}_{83}$, and high rate of mulch application (Table 4) and the greatest soil phosphorous concentrations with $\mathrm{N}_{0} \mathrm{P}_{50} \mathrm{~K}_{83}$ (Table 5).

3.8. Shoot Tissue Calcium Concentration, Uptake, and SoilSoluble Calcium Concentration. Plant tissue Ca concentration with $\mathrm{N}_{0} \mathrm{P}_{50} \mathrm{~K}_{83}$ was significantly greater than other treatments (Table 3). No notable trend observed for Ca uptake (Table 4). With high rate of sludge incorporation, soil-soluble calcium concentrations were greater than other treatments and with $\mathrm{N}_{0} \mathrm{P}_{0} \mathrm{~K}_{0}$, less than others irrespective of statistics (Table 5).

3.9. Shoot Tissue Magnesium Concentration, Uptake, and SoilSoluble Magnesium Concentration. With $\mathrm{N}_{92} \mathrm{P}_{0} \mathrm{~K}_{0}, \mathrm{~N}_{92} \mathrm{P}_{0} \mathrm{~K}_{83}$, and $\mathrm{N}_{0} \mathrm{P}_{50} \mathrm{~K}_{83}$, plant tissue $\mathrm{Mg}$ concentrations (Table 3) were significantly greater than other treatments. Remaining treatments are not significantly different with $\mathrm{N}_{0} \mathrm{P}_{0} \mathrm{~K}_{0}$. No notable trend observed for Mg uptake (Table 4).

Similar to calcium concentrations, soil-soluble magnesium concentrations were not also significantly different between treatments (Table 5). The high quantity of available calcium and magnesium in paper-mill sludge (Table 1) would be expected to increase their quantity in soil solution with mulch and incorporation, relative to other treatments. A quick deposition in soils as carbonates may prevent high quantities in solution.

3.10. Equivalent Levels of $\mathrm{Ca}, \mathrm{Mg}$, and $\mathrm{K}(\mathrm{meq} / 100 \mathrm{~g}$ Plant Dry Weight) and also the Ratios of $(\mathrm{Ca}+\mathrm{Mg}): \mathrm{K}$ in Plant Tissues and the Soil. With both incorporation treatments, $(\mathrm{Ca}+\mathrm{Mg}): \mathrm{K}$ in plant tissues was significantly greater than $\mathrm{N}_{0} \mathrm{P}_{0} \mathrm{~K}_{0}$ and irrespective of statistics greater than other treatments (Table 6). Plant tissue $\mathrm{K}$ concentrations $(\mathrm{meq} / 100 \mathrm{~g})$ with incorporations were significantly less than mulch treatments, but their $\mathrm{Ca}$ and $\mathrm{Mg}$ (meq/100 g) were not statistically different. $(\mathrm{Ca}+\mathrm{Mg}): \mathrm{K}$ ratios in plant tissues were significantly less than $\mathrm{N}_{0} \mathrm{P}_{0} \mathrm{~K}_{0}$ with $\mathrm{N}_{92} \mathrm{P}_{0} \mathrm{~K}_{83}, \mathrm{M}_{100}$, $\mathrm{N}_{0} \mathrm{P}_{0} \mathrm{~K}_{83}$, and $\mathrm{N}_{0} \mathrm{P}_{50} \mathrm{~K}_{83}$. $(\mathrm{Ca}+\mathrm{Mg}): \mathrm{K}$ in plant tissues were not significantly different from $\mathrm{N}_{0} \mathrm{P}_{0} \mathrm{~K}_{0}$ with $\mathrm{N}_{0} \mathrm{P}_{50} \mathrm{~K}_{0}$,

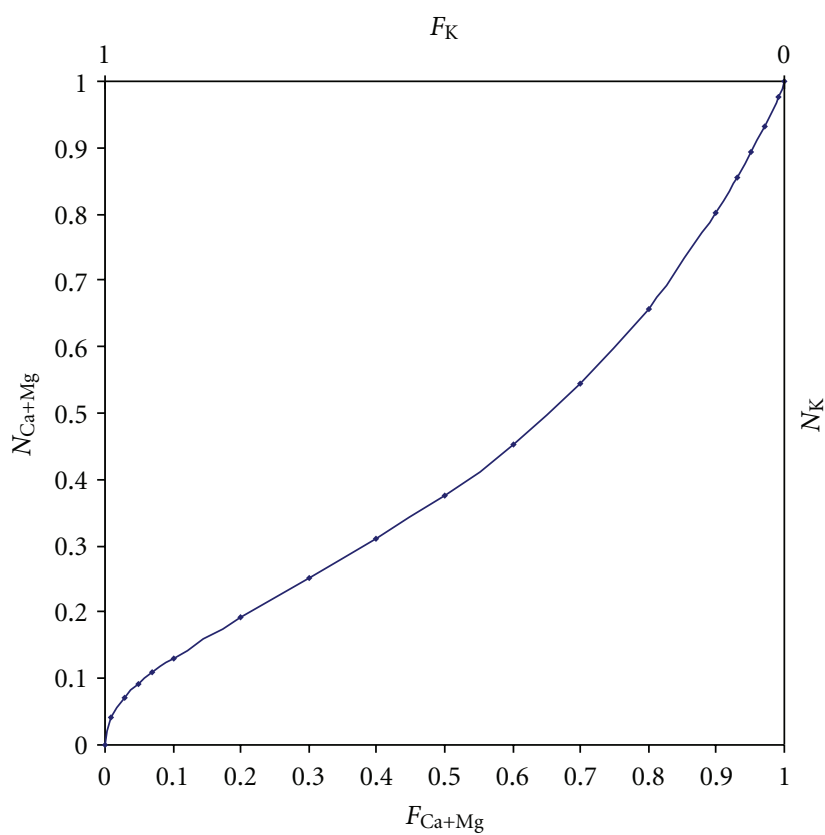

FIGURE 1: Normalized exchange isotherm following the Gapon equation for $\mathrm{K}-(\mathrm{Ca}+\mathrm{Mg})$ exchange with $\mathrm{K}_{\mathrm{G}}=16.58(\mathrm{l} / \mathrm{mole})^{0.5}$, corresponding to total electrolyte level of 0.01 normal. Ca exchange is slightly unfavorable when potassium is present except for very low concentrations.

$\mathrm{N}_{92} \mathrm{P}_{0} \mathrm{~K}_{0}, \mathrm{~N}_{92} \mathrm{P}_{50} \mathrm{~K}_{0}, \mathrm{~N}_{92} \mathrm{P}_{50} \mathrm{~K}_{83}$ and low rate of mulch. With $\mathrm{N}_{92} \mathrm{P}_{50} \mathrm{~K}_{83},(\mathrm{Ca}+\mathrm{Mg}): \mathrm{K}$ in plant tissues was significantly greater than $\mathrm{N}_{92} \mathrm{P}_{0} \mathrm{~K}_{83}$, with $\mathrm{N}_{92} \mathrm{P}_{50} \mathrm{~K}_{83}$ potassium in plant tissues (meq/100 g plant dry weight) was significantly less than $\mathrm{N}_{92} \mathrm{P}_{0} \mathrm{~K}_{83}$, and with $\mathrm{N}_{92} \mathrm{P}_{50} \mathrm{~K}_{0}$ magnesium was less than $\mathrm{N}_{92} \mathrm{P}_{0} \mathrm{~K}_{0}$ (Table 6). $\mathrm{K}, \mathrm{Ca}$, and $\mathrm{Mg}$ concentrations in soil (meq/100 g soil) at harvest were not different by these treatments (Table 6). The greatest soil $(\mathrm{Ca}+\mathrm{Mg}): \mathrm{K}$ ratio was with high rate of incorporation with a significant difference with $\mathrm{N}_{0} \mathrm{P}_{0} \mathrm{~K}_{0}$.

\section{Discussion}

$\mathrm{N}$, P, and K nutrient sources may be used as starter fertilizers for increasing tiller number per unit surface or the yield [2, chapter 10]. All treatments increased head number per square meter relative to control (Table 2). Therefore, all treatments might have worked as starters, but no significant effect on final grain and shoot yield were observed with individual N, P, or K applications. More nutrient availability in root zone with different fertilizers and sludge treatments might have enhanced root cell division and elongation after emergence in winter, leading to more absorption of nutrients and tiller production by plants. Unless the most limiting plant growth factor is met, greater tiller production does not mean a greater yield.

Short stems and heads, low heads density and weight, and the grain shrinkage were wheat potassium deficiency symptoms with both rates of sludge incorporation. Thin plants, leaf deformation with a faint color, and the chlorosis 
TABle 6: Means of meq/100 $\mathrm{g} \mathrm{K}, \mathrm{Ca}$ and $\mathrm{Mg}$ and $(\mathrm{Ca}+\mathrm{Mg}): \mathrm{K}$ ratio in soil and plant.

\begin{tabular}{|c|c|c|c|c|c|c|c|c|}
\hline Treatment & $\begin{array}{c}\text { Soil } \\
\mathrm{K}\end{array}$ & $\begin{array}{c}\text { Soil } \\
\text { Ca }\end{array}$ & $\begin{array}{l}\text { Soil } \\
\text { Mg }\end{array}$ & $\begin{array}{c}\text { Plant } \\
\mathrm{K}\end{array}$ & $\begin{array}{c}\text { Plant } \\
\mathrm{Ca}\end{array}$ & $\begin{array}{c}\text { Plant } \\
\mathrm{Mg}\end{array}$ & $\begin{array}{c}(\mathrm{Ca}+\mathrm{Mg}): \mathrm{K} \\
\quad(\text { soil })\end{array}$ & $\begin{array}{c}(\mathrm{Ca}+\mathrm{Mg}): \mathrm{K} \\
\text { (plant) }\end{array}$ \\
\hline $\mathrm{N}_{92} \mathrm{P}_{0} \mathrm{~K}_{0}$ & $0.97^{\mathrm{a}}$ & $0.25^{\mathrm{a}}$ & $0.2^{\mathrm{ab}}$ & $10.04^{\mathrm{d}}$ & $6^{\mathrm{d}}$ & $11.66^{\mathrm{a}}$ & $0.47^{\mathrm{ab}}$ & $1.75^{\mathrm{b}}$ \\
\hline $\mathrm{N}_{0} \mathrm{P}_{50} \mathrm{~K}_{0}$ & $0.98^{\mathrm{a}}$ & $0.25 a$ & $0.21^{\mathrm{ab}}$ & $8.8^{\mathrm{e}}$ & $6.83^{\mathrm{b}}$ & $9.16^{\mathrm{b}}$ & $0.48^{\mathrm{ab}}$ & $1.81^{\mathrm{b}}$ \\
\hline $\mathrm{N}_{0} \mathrm{P}_{0} \mathrm{~K}_{83}$ & $1^{\mathrm{a}}$ & $0.233^{\mathrm{a}}$ & $0.19^{\mathrm{ab}}$ & $11.74^{\mathrm{c}}$ & $6.25^{\mathrm{cd}}$ & $8.74^{\mathrm{b}}$ & $0.42^{\mathrm{ab}}$ & $1.27^{\mathrm{c}}$ \\
\hline $\mathrm{N}_{92} \mathrm{P}_{50} \mathrm{~K}_{0}$ & $0.97^{\mathrm{a}}$ & $0.26^{\mathrm{a}}$ & $0.21^{\mathrm{ab}}$ & $8.99^{e}$ & $6.25^{\mathrm{cd}}$ & $9.58^{\mathrm{b}}$ & $0.48^{\mathrm{ab}}$ & $1.75^{\mathrm{b}}$ \\
\hline $\mathrm{N}_{92} \mathrm{P}_{0} \mathrm{~K}_{83}$ & $1.04^{\mathrm{a}}$ & $0.25^{\mathrm{a}}$ & $0.21^{\mathrm{ab}}$ & $18.14^{\mathrm{a}}$ & $7.08^{\mathrm{b}}$ & $12.91^{\mathrm{a}}$ & $0.44^{\mathrm{ab}}$ & $1.1^{\mathrm{cd}}$ \\
\hline $\mathrm{N}_{0} \mathrm{P}_{50} \mathrm{~K}_{83}$ & $0.99^{\mathrm{a}}$ & $0.26^{\mathrm{a}}$ & $0.21^{\mathrm{ab}}$ & $18.66^{\mathrm{a}}$ & $8.08^{\mathrm{a}}$ & $12.91^{\mathrm{a}}$ & $0.47^{\mathrm{ab}}$ & $1.11^{\mathrm{cd}}$ \\
\hline $\mathrm{N}_{92} \mathrm{P}_{50} \mathrm{~K}_{83}$ & $1^{\mathrm{a}}$ & $0.24^{\mathrm{a}}$ & $0.173^{\mathrm{ab}}$ & $9.38^{\mathrm{de}}$ & $6.58^{\mathrm{bcd}}$ & $9.99^{\mathrm{b}}$ & $0.42^{\mathrm{b}}$ & $1.78^{\mathrm{b}}$ \\
\hline $\mathrm{I}_{50}$ & $0.87^{\mathrm{b}}$ & $0.28^{\mathrm{a}}$ & $0.24^{\mathrm{ab}}$ & $7.21^{\mathrm{f}}$ & $6.75^{\mathrm{bc}}$ & $8.61^{\mathrm{b}}$ & $0.61^{\mathrm{ab}}$ & $2.12^{\mathrm{a}}$ \\
\hline $\mathrm{M}_{50}$ & $0.98^{\mathrm{a}}$ & $0.27^{\mathrm{a}}$ & $0.23^{\mathrm{ab}}$ & $9.35^{\mathrm{de}}$ & $6.75^{\mathrm{bc}}$ & $8.74^{\mathrm{b}}$ & $0.51^{\mathrm{ab}}$ & $1.65^{\mathrm{b}}$ \\
\hline$I_{100}$ & $0.88^{\mathrm{b}}$ & $0.3^{\mathrm{a}}$ & $0.26^{\mathrm{a}}$ & $7.49^{f}$ & $6.75^{\mathrm{bc}}$ & $10^{\mathrm{b}}$ & $0.65^{\mathrm{a}}$ & $2.24^{\mathrm{a}}$ \\
\hline $\mathrm{M}_{100}$ & $1.03^{\mathrm{a}}$ & $0.29^{a}$ & $0.24^{\mathrm{ab}}$ & $16.11^{\mathrm{b}}$ & $7^{\mathrm{b}}$ & $9.99^{\mathrm{b}}$ & $0.51^{\mathrm{ab}}$ & $1.05^{\mathrm{d}}$ \\
\hline $\mathrm{N}_{0} \mathrm{P}_{0} \mathrm{~K}_{0}$ & $1^{\mathrm{a}}$ & $0.23^{\mathrm{a}}$ & $0.17^{\mathrm{b}}$ & $9.51^{\mathrm{de}}$ & $6^{\mathrm{d}}$ & $10^{\mathrm{b}}$ & $0.39^{\mathrm{b}}$ & $1.68^{\mathrm{b}}$ \\
\hline
\end{tabular}

Means within the same column followed by the same letter are not statistically different at $P=0.05$ (Fisher's LSD).

of leaf margins were apparent since May 5, 2005 with these treatments. Potassium plant tissue concentration and uptake and also the shoot and grain yield were least with both incorporation treatments. Potassium uptake and concentration with highest yielding treatments $\left(\mathrm{N}_{92} \mathrm{P}_{0} \mathrm{~K}_{83}\right.$ and high rate of sludge as mulch) were greatest, however, indicating potassium deficiency in soils. Potassium could be the target element for sludge application in these soils. Significant greater potassium uptake by $\mathrm{N}_{92} \mathrm{P}_{0} \mathrm{~K}_{83}$ and high rate of mulch compared to remaining treatments is due to greater plant growth and soil potassium availability. Accordingly low soil potassium availability to roots with both incorporation treatments could cause low potassium uptake.

The antagonist effect induced by calcium from the triple superphosphate may reduce plant potassium uptake and yield. Superphosphate with $\mathrm{N}_{92} \mathrm{P}_{50} \mathrm{~K}_{83}$ lowered potassium concentration in plant tissues (meq/100 g plant dry weight) relative to $\mathrm{N}_{92} \mathrm{P}_{0} \mathrm{~K}_{83}$ but with $\mathrm{N}_{92} \mathrm{P}_{50} \mathrm{~K}_{0}$, magnesium concentration relative to $\mathrm{N}_{92} \mathrm{P}_{0} \mathrm{~K}_{0}$, with no effect on plant tissue Ca concentration (Table 6). Ca, $\mathrm{Mg}$, and $\mathrm{K}$ compete entering roots. Soil $(\mathrm{Ca}+\mathrm{Mg}): \mathrm{K}$ ratio and exchangeable potassium affect $\mathrm{K}$ uptake by roots. Potassium and magnesium uptake by roots are adversely affected by the antagonistic effect of increased Ca concentration from superphosphate. These antagonistic effects on yield production were greater with treatments supplementing more available potassium such as $\mathrm{N}_{92} \mathrm{P}_{0} \mathrm{~K}_{83} . \mathrm{K}$, Ca, and $\mathrm{Mg}$ concentrations (meq/100 g soil) in soil at harvest were not different by superphosphate. Soil supplies for these nutrients may exceed uptakes at the end of growing season with diminishing metabolic activities, restoring initial predrilling concentrations.

Soil K (meq/100 g) and similarly plant tissue $K$ (meq/100 g) were significantly less than mulch with sludge incorporation, but no differences were found for soil and plant tissue $\mathrm{Ca}$ and $\mathrm{Mg}$ (meq/100 g). This suggests a correlation between plant tissue $\mathrm{K}$ and soil extractable $\mathrm{K}$ with $\mathrm{NH}_{4} \mathrm{OAc}$ for mulch and incorporation treatments. $(\mathrm{Ca}+\mathrm{Mg}): \mathrm{K}$ ratio in plant tissue with incorporation was greater than mulch. Potassium deficiency with incorporation treatments is due to limited potassium uptake as a result of antagonistic effects by $\mathrm{Ca}$ or $\mathrm{Mg}$. As it was noted earlier, $\mathrm{Ca}$ from triple superphosphate also reduced potassium uptake and yield by $\mathrm{N}_{92} \mathrm{P}_{50} \mathrm{~K}_{83}$ relative to $\mathrm{N}_{92} \mathrm{P}_{0} \mathrm{~K}_{83}$. Normalized exchange isotherm (Figure 1) is a case of slightly unfavorable exchange (close to linear exchange) for $\mathrm{Ca}+\mathrm{Mg}$ when $\mathrm{K}$ is present. $\mathrm{Ca}+\mathrm{Mg}$ and $\mathrm{K}$ are all mobile with an almost linear exchange. $\mathrm{Ca}+\mathrm{Mg}$ is more mobile than $\mathrm{K}$, however, due to slightly unfavorable exchange isotherm. This suggests a greater $\mathrm{K}$ : Ca ratio and plant potassium uptake in layers close to surface with organic mulch as compared to incorporation. Number of pore volume rain infiltration and nutrient mobilization (also divergence between $\mathrm{Ca}$ and $\mathrm{K}$ ) is greater in surface soil layers near mulch as compared to average $0.2 \mathrm{~m}$ incorporated plough layer. The greatest soil $(\mathrm{Ca}+\mathrm{Mg}): \mathrm{K}$ ratio at harvest was with high rate of incorporation with a significant difference with $\mathrm{N}_{0} \mathrm{P}_{0} \mathrm{~K}_{0}$ (Table 6).

Irrespective of low shoot dry matter production and grain yield relative to $\mathrm{N}_{92} \mathrm{P}_{0} \mathrm{~K}_{83}$ and $\mathrm{M}_{100}$, soil nitrate concentrations with $\mathrm{N}_{92} \mathrm{P}_{0} \mathrm{~K}_{0}$ and $\mathrm{N}_{92} \mathrm{P}_{0} \mathrm{~K}_{83}$ were both greater than all treatments at harvest, suggesting $\mathrm{N}$ could not be the most limiting plant growth factor. Least $\mathrm{N}$ uptake and tissue concentration obtained by treatments with the least dry grain and shoot dry matter production, namely, low and high rate of sludge incorporation. Stunted growth and $\mathrm{N}$ uptake with incorporation treatments is likely due to limited soil $\mathrm{N}$ and $\mathrm{K}$ availability and the root growth. A significant greater soil organic carbon percentage and total $\mathrm{N}$ at harvest by incorporation treatments relative to mulch suggests lower microbial activity and decomposition rate due possibly to high EC (Table 1), salt index, or toxicity close to sludge-incorporated particles. Salts may be leached from mulch cover by rainfall, keeping salt concentration favorable for decomposing microbial activity.

Plant tissue $\mathrm{N}$ concentration with high rate of mulch application was greater than $\mathrm{N}_{0} \mathrm{P}_{0} \mathrm{~K}_{0}$ and with $\mathrm{N}_{92} \mathrm{P}_{0} \mathrm{~K}_{83}$ was 
lower, suggesting again that soil $\mathrm{N}$ concentration is not possibly the most limiting plant growth factor. Shoot and grain yields with treatments containing only $\mathrm{N}\left(\mathrm{N}_{92} \mathrm{P}_{0} \mathrm{~K}_{0}\right)$ or $\mathrm{K}\left(\mathrm{N}_{0} \mathrm{P}_{0} \mathrm{~K}_{83}\right)$ were not different with $\mathrm{N}_{0} \mathrm{P}_{0} \mathrm{~K}_{0}$, suggesting ammonium ion from urea, neither potassium from potassium sulfate fertilizers affect soil potassium availability. The ammonium ion from urea fertilizer with $\mathrm{N}_{92} \mathrm{P}_{0} \mathrm{~K}_{83}$ may increase potassium residence time and concentration in diffuse double layer and soil solution in potassium-fixing soils (containing illite) and, hence, plant tissue concentration and uptake (Table 4). High soil potassium concentration with $\mathrm{N}_{92} \mathrm{P}_{0} \mathrm{~K}_{83}$ at harvest supports this conclusion. Rezaei and Movahedi Naeini [23] found that ammonium increased potassium desorption in batch experiments with these soils. Yield is expected to increase with high rate of mulch with a similar mechanism involving both ammonium and potassium ions.

\section{Conclusions}

Decomposition rate with sludge mulch was greater than incorporation. Optimal application rate of sludge application for nutrient supply is less for mulch than incorporation. $100 \mathrm{t} /$ ha sludge with $22.4 \% \mathrm{C}$ by mulch application adds $1 \%$ OC to top $0.2 \mathrm{~m}$ surface soil with many benefits to arid and semiarid soils.

Cations released by sludge decomposition are diverged along their traveling path in soil due to their nonlinear exchange isotherm and variable mobility. Due to greater rain infiltration, traveling distance and divergence is greater for surface applied cations by mulch relative to incorporation. Cation competition for entering roots and their antagonistic effects is minimized by mulch application.

Plant potassium uptake and yield were both increased by paper-mill sludge application as mulch but decreased as incorporation in this research. Great care must be exercised with conventional tillage where mulch is eventually ploughed under and incorporated. Since sludge mulch is eventually ploughed under, two consecutive trials are suggested for future research, with mulch first and then with incorporation. Paper-mill sludge could be used successfully for alleviating soil potassium deficiency if no detrimental effect is detected on yield with the second trial after incorporation.

Heavy metal additions by 50 and 100 t/ha dry weight sludge applications (Table 1) were not excessive and hazardous [24]. Mineralization rate with high rate of mulch application was greater than incorporation. A greater yield by mulch suggests no adverse effect by chlorotic organic compounds such as dioxins isomers, furans, and polychlorinated biphenyls. Likelihoods of excessive hazardous organic compounds and heavy metal load must be considered prior to sludge application. This likelihood is greater with frequent applications.

High $(\mathrm{Ca}+\mathrm{Mg}): \mathrm{K}$ in soil solution creates a tense competition between $\mathrm{Ca}+\mathrm{Mg}$ and $\mathrm{K}$ for entering roots in soils with high specific surface [20] and low potassium diffusion to soil solution. Therefore, even short-lived sources of increased $\mathrm{Ca}$ and $\mathrm{Mg}$ in soil solution are expected to disturb potassium uptake. In these soils containing illites, potassium uptake by roots is adversely affected by calciumbearing superphosphate. Other potassium- or ammoniumbased phosphates are recommended for future research and were already applied successfully by Talebizadeh and Movahedi Naeini [25].

\section{Funding Source}

This research was funded by Gorgan University of Agricultural Sciences and Natural Resources (Iran).

\section{References}

[1] S. K. Jalota and S. S. Prihar, "Bare-Soil Evaporation in Relation to Tillage," Advances in Soil Science, vol. 12, pp. 187-212, 1990.

[2] J. L. Havlin, J. D. Beaton, S. L. Tisdale, and W. L. Nelson, Soil Fertility and Fertilizers, Prentice Hall, 2005.

[3] C. A. Francis, R. R. Harwood, and J. F. Parr, "The potential for regenerative agriculture in the developing world," American Journal of Alternative Agriculture, vol. 1, pp. 65-74, 1986.

[4] A. Wild, Russells Soil Conditions and Plant Growth, Wiliams Clowes Limited, London, UK, 11th edition, 1988.

[5] NCASI, "The land application and related utilization of pulp and paper mill sludges," Tech. Bulletin No. 439. New York, NY, USA, 1984.

[6] NCASI, "Characterization of wastes and emissions from mills using recycled paper," Tech. Bulletin No. 613. New York, NY, USA, 1991.

[7] A. Wallace and A. E. Terry, Hand Book of Soil Conditioners, Marcel Dekker, New York, NY, USA, 1998.

[8] G. Sposito, The Chemistry of Soils, Oxford University Press, 2nd edition, 2008.

[9] G. H. Bolt and M. G. M. Bruggenwert, Soil Chemistry, Part A. Basic Elements, Elsevier, Dordrecht, The Netherlands, 1978.

[10] F. Farhangi, Influence of soil incorporated calcium sulfate, calcium chloride and potassium chloride on the release of available $K$ from two soils, with and without truncated electric diffuse double layers using breakthrough curves, M.S. thesis, Soil Science Department, Gorgan University of Agricultural Sciences and Natural Resources, Gorgan, Iran, 2011.

[11] B. F. Pain, "Nutritional requirements of forage maize," in Forage Maize, E. S. Bunting, B. F. Pain, R. H. Phipps, J. M. Wilkinson, and R. E. Gunn, Eds., pp. 87-116, Agricultural Research Council, London, UK, 1978.

[12] R. D. Munson, "Interaction of potassium and other ions," in The Role of Potassium in Agriculture, American Society of Agronomy, Crop Society of America, Soil Science Society of America, Madison, Wis, USA, 1968.

[13] W. L. Lindsay, Chemical Equilibria in Soils, John Wiley \& Sons, New York, NY, USA, 1979.

[14] A. L. Page, R. H. Miller, and D. R. Keeney, Methods of Soil Analysis, Part 2. Chemical and Microbiological Properties, American Society of Agronomy, Inc. Soil Science Society of America, Madison, Wis, USA, 1986.

[15] A. Klute, Methods of Soil Analysis, Part 1. Physical and Mineralogical Methods, American Society of Agronomy, Soil Science Society of America, Madison, Wis, USA, 1986.

[16] J. A. Kittric and E. W. Hope, "A procedure for particle size separations of soils for X-ray diffraction," Soil Science Society of America Proceedings, vol. 35, pp. 621-626, 1971. 
[17] W. D. Johns, R. E. Grim, and W. F. Bradley, "Quantitative estimation of clay minerals by diffraction method," Journal of Sedimentary Petrology, vol. 24, pp. 242-251, 1954.

[18] R. L. Westerman, Soil Testing and Plant Analysis, Soil Science Society of America, Madison, Wis, USA, 2005.

[19] USEPA, Guide to Part 503 Rule. Land application of Biosolids, U.S. GOV. Print, Washington, DC, USA, 1995.

[20] S. Amini, The effect of paper-mill sludge on soil fertility and wheat growth, M.S. thesis, Soil Science Department, Gorgan University of Agricultural Sciences and Natural Resources, Gorgan, Iran, 2007.

[21] G. H. Bolt, Soil Chemistry, Part B. Physico-Chemical Models, Elsevier, Dordrecht, The Netherlands, 1979.

[22] M. B. McBride, Environmental Chemistry of Soils, Oxford University Press, New York, NY, USA, 1994.

[23] M. Rezaei and S. A. R. Movahedi Naeini, "Effects of Ammonium and Iranian natural zeolite on potassium adsorption and desorption kinetics in the loess soil," International Journal of Soil Science, vol. 4, no. 2, pp. 27-45, 2009.

[24] National Research Council, Biosolids Applied to Land, National Academy Press, Washington, DC, USA, 2002.

[25] E. Talebizadeh and S. A. R. Movahedi Naeini, "The effects of different potassium mixed fertilizers on wheat growth and yield in a soil with a high specific surface," in Proceedings of 11th Iran Congress of Soil Science, Gorgan, Iran, July 2009. 

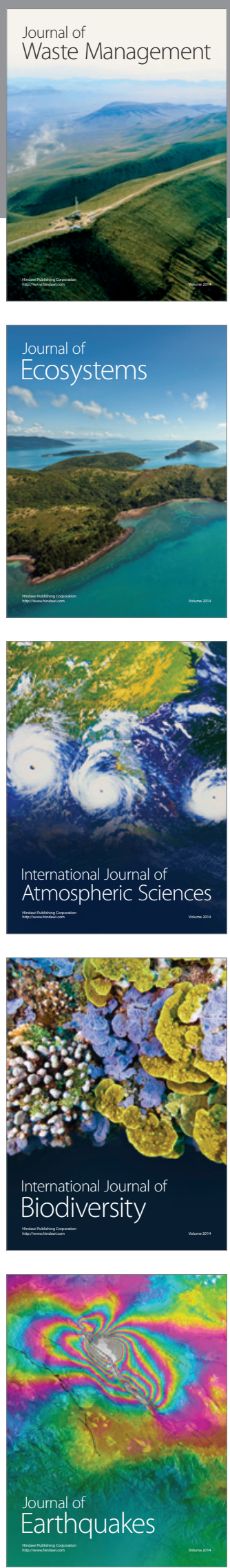
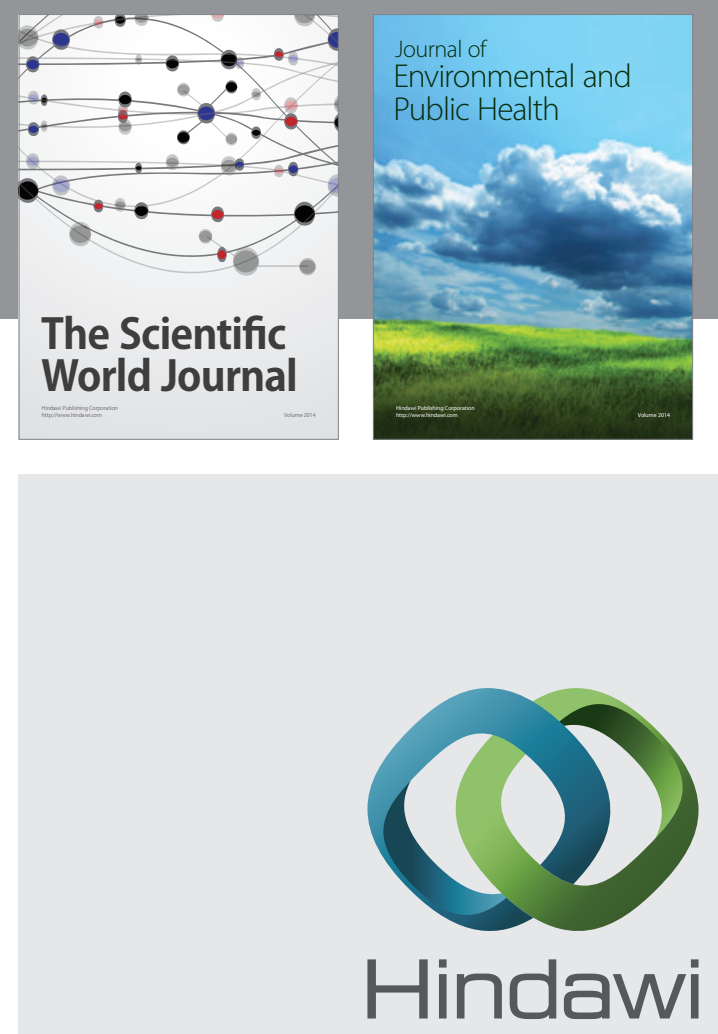

Submit your manuscripts at

http://www.hindawi.com
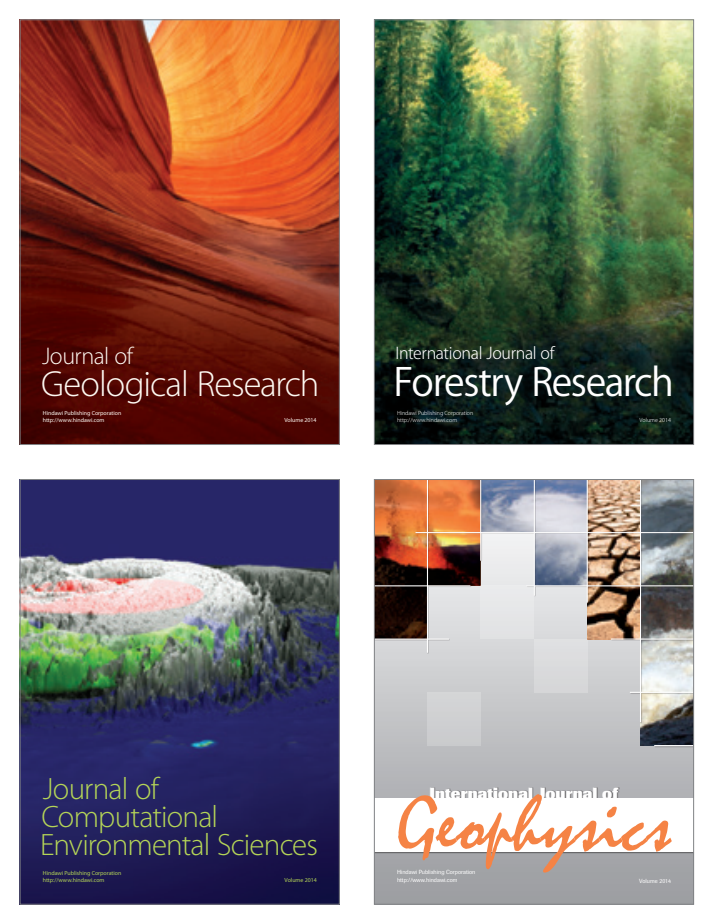
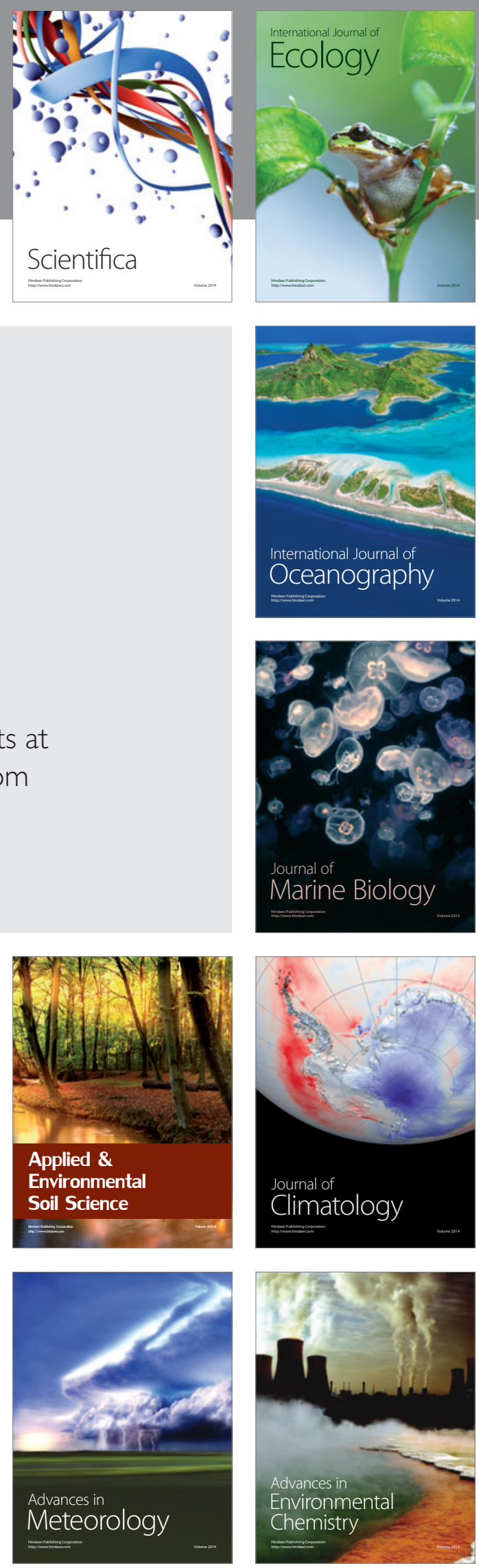